\title{
PENERAPAN NILAI-NILAI PENDIDIKAN AGAMA ISLAM DALAM PERKEMBANGAN TEKNOLOGI INFORMASI MOBILE DI MADRASAH ALIYAH MANARATUL ISLAM
}

\author{
Nur Ali ${ }^{1}$, Eddy Saputra ${ }^{2}$, Rayung Wulan ${ }^{3}$ \\ Program Studi Teknik Informatika, Universitas Indraprasta PGRI \\ Email: nurali7896@yahoo.com¹, saputra2578@gmail.com²,utha2578@gmail.com³
}

\begin{abstract}
Abstrak
Pendidikan Agama Islam di dalam lingkungan sekolah merupakan salah satu mata pelajaran yang wajib diikuti oleh seluruh siswa/i dengan tujuan pendidikan Agama Islam diberikan dengan mengikuti tuntutan bahwa Agama diajarkan pada manusia dengan visi untuk mewujudkan manusia yang bertaqwa kepada ALLAH SWT dan berakhlak mulia. Dunia remaja merupakan masa-masa yang sangat emas, masa tersebut sering disebut sebagai "Golden Age". Remaja umumnya berada pada cluster atau kelompok di dunia pendidikan sekolah menengah tingkat atas, di masa-masa itulah remaja dengan perkembangan teknologi yang sangat pesat menjadikan kebutuhan dunia teknologi yang serba instant. Remaja di suguhkan dengan fenomenal-fenomenal teknologi informasi yang serba instant atau yang umum disebut mobile, kapan dan di manapun tidak ada keterbatasan waktu dan tempat. Dengan diartikan di sekolahpun dengan ponsel remaja bisa menggunakan. Dunia pendidikan sudah kurang mampu membendung tingginya arus globalisasi teknologi informasi mobile, adanya pendidikan Agama pun dirasakan kurang mampu menekan masalah yang ada pada remaja.
\end{abstract}

Kata Kunci: Pendidikan Agama Islam, TI Mobile, Remaja Madrasah Aliyah

\section{Pendahuluan}

Dunia remaja merupakan masa-masa yang sangat emas, masa tersebut sering disebut sebagai "Golden Age" . Lebih lanjut (Thornburgh, 2003) membagi usia remaja menjadi tiga kelompok, yaitu:

a. Remaja awal: antara usia 11 hingga usia 13 tahun.

b. Remaja pertengahan: antara usia 14 hingga usia 16 tahun.

c. Remaja akhir: antara usia 17 hingga usia 19 tahun.

Sistem aplikasi mobile merupakan aplikasi yang dapat digunakan walaupun pengguna berpindah dengan mudah dari satu tempat ke tempat lain lain tanpa terjadi pemutusan atau terputusnya komunikasi (Nasruddin Safaat, 2012). Lebih lanjut dikatakan bahwa di sekolah pada era teknologi maju dewasa ini membutuhkan orang yang sangat kompeten dan trampil untuk mengelola teknologi informasi tersebut. Ketidakmampuan remaja mengikuti perkembangan teknologi yang demikian cepat harus diimbangin oleh tanggung jawabnya sebagai remaja. Sehingga di sekolah pendidikan Agama dirasakan mampu menekan arus era globalisasi teknologi informasi. Nilai-nilai pendidikan Agama Islam diharapkan mampu membawa pengaruh yang cukup kuat dalam perkembangan teknologi informasi mobile saat ini. Di mana saat ini remaja pengguna teknologi informasi mobile (gadgate) mencapai 83\% (Rosdianah Dewi, 2003).

Remaja menjadi sasaran utama dalam pembaharuan di dalam perkembangan teknologi informasi mobile, setiap ada yang baru umumnya remajalah yang menjadi objek percontohan. Apakah teknologi informasi mobile yang baru dapat mudah masuk di dalam kalangan remaja. Fenomena remaja pengguna teknologi informasi mobile sering kita jumpai diberbagai tempat, baik ketika kita sedang berjalan di pusat perbelanjaan, sekolah, tempat hiburan, ataupun tempat rekreasi. Dikarenakan fungsi teknologi informasi mobile sudah 
menjadi satu dengan ponsel. Setiap remaja mempunyai peranan yang berbeda dalam menggunakan suatu teknologi informasi mobile terbaru. Sebagian remaja mampu menerima dan menggunakan teknologi informasi mobile terbaru dengan aturan yang ada sebagian lainnya hanya sekedar tau ataupun mengenalnya saja.

Berdasarkan statistik yang dikeluarkan oleh International Telecommunication Union (ITU) pada akhir Desember 2014 jumlah pengguna teknologi informasi mobile (ponsel) mencapai 4,6 milyar di seluruh Indonesia dan $80 \%$ penggunanya adalah remaja. Kini berbagai jenis jenis teknologi informasi mobile sudah banyak jenisnya dan dilengkapi dengan berbagai macam fasilitas-fasilitas yang sangat menjanjikan di kalangan remaja. Seiring dengan berkembangnya waktu tanpa disadari adanya pergeseran teknologi informasi mobile yang awalnya hanya sebagai komunikasi kini menjadi media penyedia informasi pendidikan ataupun penyedia hiburan yang sangat fleksibel.

\section{Tinjauan Pustaka}

\section{Teknologi Informasi Mobile}

Seiring dengan peningkatan teknologi informasi mobile di masyarakat dan bisnis, banyak individu dan organisasi yang secara serius mempertimbangkan penggunaan perangkat mobile untuk media pembelajaran di sekolah. Namun demikian, teknologi informasi mobile sering digunakan tanpa mempertimbangkan aspek yang akan dicapai dalam media pembelajaran. Teknologi Informasi mobile merupakan media learning sebagai penyampaian sarana pembelajaran elektronik pada alat komuniakasi mobile (Ally, et.al, 2005). Teknologi informasi mobile pada dasarnya sebagai penggabungan media sosial dengan model-model seperti majalah, forum, weblogs, sosial blogs, microblogging, video dan lain sebagainya. Meningkatnya kemajuan teknologi membuat akses informasi dari luar dengan mudahnya masuk ke dalam negeri.

Era globalisasi yang berkembang dengan pesat saat ini membuat teknologi yang dibuat oleh penemu-penemu dunia sampai juga ditangan masyarakat umum yang haus akan sesuatu baru. Rasa penasaran ini membuat masyarakat menggunakan teknologi yang ada. Rasa penasaran yang terbesar adalah dialami oleh para remaja. Remaja yang notabene masih labil dalam mental dan perilaku, membuat remaja mempunyai rasa penasaran lebih besar dibandingkan dengan orang dewasa yang stabil dalam mental dan perilaku. Terlebih dengan hal-hal yang baru, terutama hal-hal baru tentang teknologi. Teknologi memang menjadi hal yang masih sering diperdebatkan antara manfaat dan dampaknya. Tidak dapat dipungkiri bahwa teknologi memiliki beberapa manfaat yang sangat membantu kehidupan manusia pada jaman sekarang (Jogiyanto, 2005). Tapi juga tidak dapat dipungkiri bahwa teknologi memiliki dampak yang tidak kalah banyaknya dengan manfaat dari teknologi itu sendiri.

Bermacam-macam teknologi tersedia di era globalisasi, kemajuan teknologi menyediakan bervariasi teknologi untuk berbagai bidang (Jogiyanto, 2005). Sebut saja bidang informasi dan komunikasi. Karena kemajuan teknologi dalam bidang inilah yang lebih familiar di telinga para remaja. Tengok saja di sekeliling lingkungan kita saat ini. Tentu dengan mudahnya ditemukan teknologi dalam bidang informasi dan komunikasi. Tengok juga orang-orang yang ada di lingkungan kita. Pengaruh kemajuan teknologi dalam bidang inilah terlihat sangat jelas. Kecanduan teknologi dalam bidang informasi dan komunikasi memang sangat mudah dilihat, terutama jika kecanduan itu dialami oleh remaja. Sebut saja kecanduan internet dalam bidang informasi dan kecanduan pada handphone dalam bidang komunikasi. Kecanduan yang dapat mengubah gaya hidup remaja jaman sekarang. 


\section{Pendidikan Agama Islam}

Nilai nilai pendidikan Agama Islam diharapkan mampu membawa pengaruh yang cukup kuat dalam perkembangan teknologi informasi mobile saat ini. Dengan menerapkan pendidikan agama yang kuat, remaja akan menyadari manfaat, kebutuhan dan keinginannya. Dengan kata lain Agama sebagai dasar pijakan umat manusia memiliki peran yang sangat besar dalam proses kehidupan manusia. Agama telah mengatur pola hidup manusia baik dalam hubungannya dengan Tuhannya maupun dalam menyikapi perkembangan teknologi mobile yang saat ini remaja menjadi sasaran utama dalam perkembangannya (Drajat Zakiah, 2002).

Pendidikan Agama Islam merupakan suatu sistem pendidikan yang mencakup seluruh aspek kehidupan yang dibutuhkan oleh umat manusia dalam rangka meningkatkan kehidupan bermasyarakat, beragama, berbangsa dan bernegara. Pendidikan agama Islam adalah bimbingan jasmani, rohani berdasarkan hukum hukum agama menuju kepada terbentuknya kepribadian utama menurut ukuran Islam (Marimba Ahmad, 2000)

\section{Remaja dan Teknologi Informasi Mobile}

Dunia remaja merupakan masa masa yang sangat emas, masa tersebut sering disebut sebagai "Golden Age" . Lebih lanjut (Thornburgh, 2003) membagi usia remaja menjadi tiga kelompok, yaitu:

a. Remaja awal: antara usia 11 hingga usia 13 tahun.

b. Remaja pertengahan: antara usia 14 hingga usia 16 tahun

c. Remaja akhir: antara usia 17 hingga usia 19 tahun

Remaja menjadi sasaran utama dalam pembaharuan di dalam perkembangan teknologi informasi mobile, setiap ada yang baru umumnya remajalah yang menjadi objek percontohan. Apakah teknologi informasi mobile yang baru dapat mudah masuk di dalam kalangan remaja. Fenomena remaja pengguna teknologi informasi mobile sering kita jumpai di berbagai tempat, baik ketika kita sedang berjalan di pusat perbelanjaan, sekolah, tempat hiburan, ataupun tempat rekreasi. Dikarenakan fungsi teknologi informasi mobile sudah menjadi satu dengan ponsel. Setiap remaja mempunyai peranan yang berbeda dalam menggunakan suatu teknologi informasi mobile terbaru. Sebagian remaja mampu menerima dan menggunakan teknologi informasi mobile terbaru dengan aturan yang ada sebagian lainnya hanya sekedar tau ataupun mengenalnya saja.

Berdasarkan statistik yang dikeluarkan oleh International Telecommunication Union (ITU) pada akhir Desember 2012 jumlah pengguna teknologi informasi mobile (ponsel) mencapai 4,6 milyar diseluruh Indonesia dan $80 \%$ penggunanya adalah remaja. Kini berbagai jenis jenis teknologi informasi mobile sudah banyak jenisnya dan dilengkapi dengan berbagai macam fasilitas fasilitas yang sangat menjanjikan dikalangan remaja. Seiring dengan berkembangnya waktu tanpa disadari adanya pergeseran teknologi informasi mobile yang awalnya hanya sebagai komunikasi kini menjadi media penyedia informasi pendidikan ataupun penyedia hiburan yang sangat fleksibel. Ini merupakan salah satu masalah remaja yang hendaknya diperhatikan sedini mungkin, karena remaja adalah generasi penerus bangsa yang seharusnya memiliki moral yang baik dan dapat memanfaatkan teknologi informasi mobile sesuai dengan kebutuhannya.

Sekolah umunya tidak melarang siswa/i menggunakan gadgate di lingkungan sekolah, padahal di lingkungan sekolahlah waktu mereka para pelajar yang paling banyak. Memberikan isyarat bahwa di lingkungan sekolah mempunyai kewajiban tugas guru serta aturan sekolah untuk mendidik remaja baik dalam kaitannya dengan proses belajar-mengajar yang sedang dialaminya di lingkungan sekolah maupun dalam upaya memberikan kesiapan 
untuk menghadapi lajunya perkembangan teknologi inforamsi mobile di sekolah atau sebagai upaya sosialisasi terhadap remaja, sehingga dapat menjadi masyarakat yang berguna dan mampu menyesuaikan diri.

Selain hal-hal yang telah disebutkan di atas, yang dapat mendorong orang tua agar mendidik remaja di lingkungan keluarga, ada lagi satu hal yang perlu diperhatikan yaitu; mengingat kondisi remaja itu sendiri, baik secara fisik maupun mental ia mutlak memberikan bimbingan dan pengembangan ke arah yang positif. Kalau tidak maka dikhawatirkan fitrah yang tersimpan, yang merupakan benih-benih bawaan itu akan terlantar atau akan menyimpang.

Perlu diingat bahwa pada diri anak itu terdapat kecenderungan-kecenderungan ke arah yang baik, akan tetapi dilengkapi dengan kecenderungan ke arah yang jahat. Maka tugas pendidik dalam hubungan ini adalah menghidup-suburkan kecenderungan ke arah yang baik. Suatu pengaruh pendidikan yang paling pundamental dan fungsional dalam pribadi, bilamana pengaruh tersebut ditanamkan dalam pribadi anak yang masih berada pada awal perkembangannya (Arifin, E. Ed, 2001). Pengaruh tersebut akan menjadi benih utama yang dapat berpengaruh dalam perkembangannya lebih lanjut.

Remaja merupakan pribadi yang unik dan energik. Banyak potensi diri yang mungkin ada dalam dirinya, yang sebenarnya telah ada di dalam diri mereka sejak mereka dilahirkan. Hanya saja butuh proses untuk menggalinya. Selain keluarga dan masyarakat, sekolah merupakan tempat menggali potensi diri. Karena di lembaga ini, mereka belajar secara sistematis untuk mendapatkan ilmu pengetahuan.

Media yang saat ini sangat digandrungi oleh kalangan remaja adalah media teknologi informasi mobile. Teknologi informasi mobile yang selanjutnya disingkat menjadi TIM berkembang sangat cepat, hal ini terjadi karena adanya kebutuhan dari konsumen. TIM merupakan segala bentuk teknologi yang menunjang penyampaian informasi dan pelaksanaan komunikasi searah, dua arah, atau bahkan lebih (Kwartolo, 2010). Dan menurut (Wijaya, 2007), penggunaan TIM secara benar dan tepat memberikan kontribusi memperluas akses dalam meningkatkan kualitas pembelajaran yang terdigitalisasi.

Menurut (Prawiradilaga dan Siregar, 2008) media komunikasi berfungsi untuk:

1. Memberikan pengetahuan tentang tujuan belajar. Guru harus menunjukkan keterampilan apa yang diharapkan akan dicapai oleh siswa setelah mempelajari materi pembelajaran.

2. Memotivasi siswa. Jika siswa yakin mengenai relevansi pembelajaran dengan kebutuhan di masa depan, ia akan termotivasi untuk mengikuti pembelajaran.

3. Menyajikan informasi. Ada tiga jenis variasi penyajian informasi yaitu dengan penyajian dasar, penyajian pelengkap, dan penyajian pengayaan.

4. Merangsang diskusi. Penyajian informasi dibiarkan terbuka (open-ended), tidak ada penarikan simpulan ataupun pemecahan masalah. Hal ini nantinya, merangsang pemikiran siswa. Sehingga timbul pertanyaan-pertanyaan.

5. Mengarahkan kegiatan siswa. Dengan media, siswa diarahkan melakukan setiap kegiatan langkah demi langkah, mulai dari yang mudah sampai yang sukar.

6. Melaksanakan latihan dan ulangan. Dengan media komunikasi khususnya komputer, penyajian latihan dan ulangan dapat dilakukan terus-menerus.

7. Menguatkan belajar. Media komunikasi dirancang sedemikian rupa agar mampu menyajikan pertanyaan dan merangsang siswa untuk menjawab. Saat siswa mampu menjawab dengan benar, ia merasakan motivasi bahwa ia dikuatkan, sebaliknya ketika jawabannya salah, evaluasi dari jawabannya dapat menguatkan ia untuk mencari jaaban yang benar. 
8. Memberikan pengalaman simulasi. Media komunikasi mampu memberikan simulasi yang memberikan gambaran lingkungan buatan yang secara realistis dapat merangsang siswa mengembangkan kemampuan dirinya.

\section{Metodologi Penelitian}

Metode atau model yang digunakan dalam penulisan ini adalah metode kualitatif dan deskriptif dengan menggunakan model Jalahudin yang dianggap dapat membuat model penelitian yang bersifat kualitatif dikarenakan model Jalahudin menjelaskan secara lengkap Analisis data dalam penelitian kualitatif, dilakukan pada saat pengumpulan data berlangsung, dan setelah selesai pengumpulan data dalam periode tertentu. Jalahudin mengemukakan remaja umumnya memiliki rasa ingin mencoba terhadap perkembangan teknologi mobile sangat tinggi sehingga mengabaikan tugas pokoknya sebagai pelajar, karena tidak adanya aturan yang mewajibkan mereka untuk mentaati. Dilihat dari tiga kutub masyarakat, Perkembangan Teknologi Informasi Mobile dan sekolah.

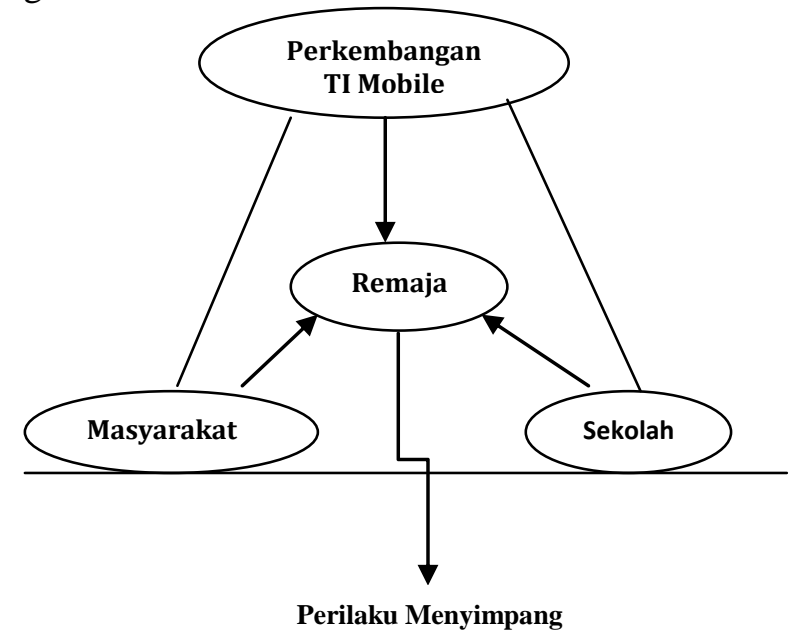

\section{Gambar 1. 3(tiga) kutub prilaku remaja} Sumber (Jalahudin, 2008)

Aktivitas dalam analisis data, yaitu data reduction, data display dan conclusion drawing/ferification. Sugiyono ( $2012: 246$ ), dengan mendisplaykan data maka akan memudahkan untuk memahami apa yang terjadi, merencanakan kerja selanjutnya berdasarkan apa yang telah dipahami tersebut. Langkah selanjutnya dalam analisis data kualitatif menurut Jalahudin adalah penarikan Simpulan dan verifikasi. Simpulan awal yang dikemukakan masih bersifat sementara, dan berubah bila tidak ditemukan bukti-bukti yang kuat yang mendukung pada tahap pengumpulan data berikutnya.

Metode penelitian deskriptif yaitu menguraikan atau menggambarkan permasalahan yang diteliti dengan menggunakan tulisan atau referensi. Dilakukan dengan cara menganalisis permasalahan yang ada lalu dikemukakan dari berbagai referensi dan membandingkan sehingga mendapatkan hasil.

\section{Hasil dan Pembahasan}

\section{Analisis Nilai Nilai Pendidikan Agama Islam}

Hasil Analisis dari penelitian ini adalah membuat model atau metode yang cocok di lingkungan sekolah MA Manaratul Islam dikarenakan di lingkungan sekolah tersebut rawan akan maraknya penggunaan teknologi informasi mobile yang berlebihan. Selain itu juga memberikan metode pengenalan dasar tentang Teknologi Informasi Mobile yang sedang marak di kalangan remaja. 
Dengan hasil yang telah tercapai maka dapat dievaluasi metode yang sudah diterapkan dan membandingkan sesudah dan sebelum adanya penelitian ini.

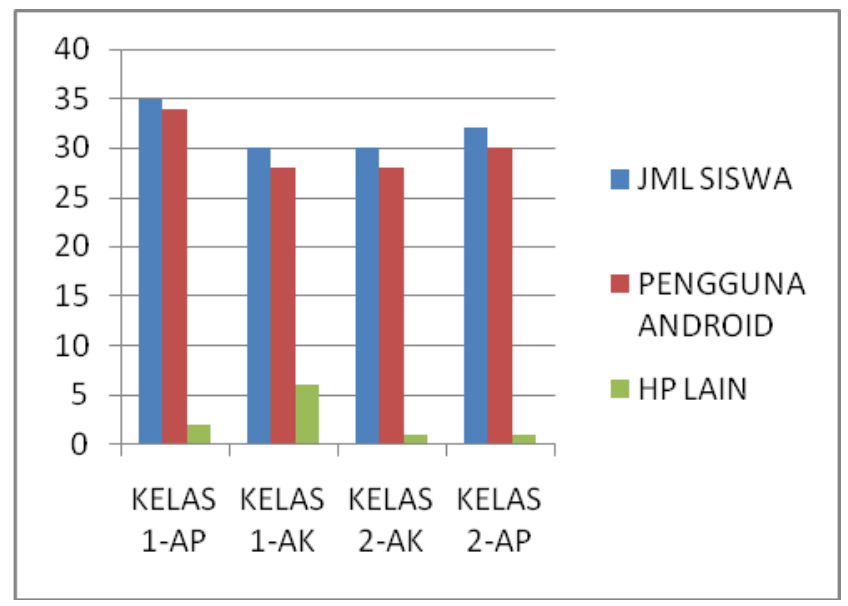

\section{Gambar 2. Hasil Analisis Pengguna Android Sumber (Hasil perhitungan di MA , 2014)}

Khusus dalam kegiatan pembelajaran terhadap nilai pendidikan agama diperoleh hasil antara lain:

1. Pembelajaran menjadi lebih efektif, simulatif dan menarik bagi siswa/i.

2. Dapat menjelaskan sesuatu sulit/kompleks.

3. Mempercepat proses yang lama.

4. Menghadirkan peristiwa yang jarang terjadi.

5. Menunjukan peristiwa yang berbahaya atau diluar jangkauan.

\section{Analisis Teknologi Informasi Mobile terhadap Remaja}

Dengan adanya Handphone android yang seharusnya dapat memudahkan siswa dalam belajar, seperti Laptop dengan jaringan internet, ini malah sering membuat siswa menjadi malas belajar, terkadang banyak di antara mereka yang menghabiskan waktunya untuk internetan yang hanya mendatangkan kesenangan semata, seperti; Facebook, Chating, Frienster dan lain-lain, yang semuanya itu tentu akan berpengaruh terhadap minat belajar siswa.

Munculnya metode-metode pembelajaran yang baru, yang memudahkan siswa dan guru dalam proses pembelajaran, sehingga membuat siswa menjadi malas. Dengan adanya fasilitas yang dapat digunakan dengan mudah dalam proses pembelajaran, ini terkadang sering membuat siswa dan mahasiswa menjadi malas dan merasa lebih dimanjakan, misalnya ketika siswa diberi tugas untuk membuat makalah, maka mereka merasa tidak perlu pusingpusing, karena cukup mencari bahan lewat internet dan mengcopy paste karya orang lain, sehingga siswa menjadi malas berusaha dan belajar.

\section{Simpulan dan Saran}

\section{Simpulan}

1. Penerapan nilai nilai pendidikan agama Islam sangat dibutuhkan keberadaannya di lingkungan pelajar dalam rangka memotivasi remaja.

2. Perkembangan teknologi informasi sangat berpengaruh di kalangan remaja sekolah menengah atas.

3. Laju perkembangan teknologi informasi harus dibentengi oleh nilai nilai pendidikan agama Islam.

\section{Saran}


1. Mengevaluasi siswa/i dis ekolah tingkat atas terhadap perkembangan teknologi informasi.

2. Memberikan masukan kepada pihak sekolah untuk mengarahkan siswa/i dengan memberikan pelayanan jasa. Dengan cara mengundang tenaga IT untuk menjelaskan keberagaman perkembangan Teknologi Informasi mobile serta fungsi dan kegunaannya.

\section{Daftar Pustaka}

Diah, M. (2007). Suatu Tinjauan Motivasi pada Pendidikan Remaja. Jakarta: Gramedia.

Thornburgh. (2003). "Golden Age” Remaja dan Dunianya. PT. Indeks.

Hollingsworth P., Lewis G. (2008). Pembelajaran Aktif. PT. Indeks.

Honiatri, E. (2008). Mengaplikasikan Keterampilan Dasar Komunikasi SMK. rmico,Bandung.

Rosdianah Dewi. (2003). Belajar dan Pembelajaran. Jakarta: Dunia Pustaka Jaya.

Purwanto, N. (2004). Landasan Kependidikan. Jakarta: PT Rineka Cipta.

Sudjana, N. (2000). Active Learning: 101 Strategi Pembelajaran Aktif.Yogyakarta: PT. Pustaka Insan Madani.

Sudjana, N. (2001). Dasar-Dasar Proses Belajar Mengajar. Bandung: Sinar Baru Algensindo.

Sudjana, N. (2004). Penilaian Hasil Belajar Mengajar. Bandung: Remaja Rosdakarya.

Suhendar, T. (2009). Landasan Psikologi Proses Pendidikan. PT Remaja Rosdakarya.

Syaiful, S.B. (2008). Penelitian Tindakan Kelas. Jakarta: Departemen Pendidikan Nasional.

Miles and Huberman. (2004), Teori dan Aplikasi Metode Penelitian. Cups publishing.

Jalahudin. (2008). Remaja dan Dunianya. Jakarta: Dunia Pustaka Jaya. 